\title{
DELEUZE, HEGEL, AND THE POST-KANTIAN TRADITION
}

Daniel W. Smith

Gilles Deleuze has often been characterized as an "anti-dialectical" and hence "anti-Hegelian" thinker. Evidence for these characterizations is not difficult to amass. In his well-known "Letter to Michel Cressole" (reprinted in Negotiations as "Letter to a Harsh Critic"), Deleuze, while discussing his post-war student days in the 40s and 50s, says explicitly that, at the time, "what I detested most was Hegelianism and the dialectic." Nietzsche and Philosophy, which Deleuze published in 1962, is an avowedly anti-Hegelian tract; its final chapter bears the ominous title, "Against the Dialectic." Even as late as 1968, Deleuze writes that the themes of his magnum opus, Difference and Repetition, were in part attributable, as he states in its preface, "to a generalized anti-Hegelianism." This theme is echoed by Vincent Descombes, in his influential book Modern French Philosophy, who characterizes the entire generation of philosophers to which Deleuze belongs-which includes Jacques Derrida, Michel Foucault, Jean-François Lyotard, and Michel Serres-by their reaction against Hegel (and in particular against Alexandre Kojève's reading of Hegel). ${ }^{4}$ Foucault himself noted in his inaugural lecture at the Collège de France: "Whether through logic or epistemology, whether through Marx or Nietzsche, our entire epoch struggles to disengage itself from Hegel.".'

These characterizations have been repeated so often in the secondary literature that they have assumed an almost canonical status. They are the lens through which Deleuze's thought is inevitably read and interpreted, to the point where they have become clichés (in Deleuze's sense of this term) that prejudge the nature of his thought and pre-program its interpretation and reception. Such characterizations, however, are at best partial and at worst inaccurate. Deleuze is not an anti-dialectical thinker as such: one of the explicit aims of Difference and Repetition is to propose a new conception of dialectics, based on a principle of difference rather than a model of contradiction. ${ }^{6}$ In this sense, Deleuze's early anti-Hegelianism is primarily polemical, and must be understood in the context of the revised theory of Ideas proposed in Difference and Repetition. In what follows, I would like to defend these claims, not by analyzing Deleuze's reading of Hegel as such, but rather by analyzing the context in which that reading should be understood. That context not only includes Deleuze's relation to the history of philosophy in general, but more particularly his relation to the post-Kantian tradition to which Hegel belongs. In his early work, when his anti-Hegelian polemics were strongest, Deleuze undertook a revisionary interpretation of the entire post-Kantian tradition-an interpretation in which the work of Salomon Maimon played a pivotal role. Deleuze's explicit critiques of Hegel, and his renewed concept of dialectics, should be understood in terms of the broader project Deleuze was pursuing in his work prior to the writing of Difference and Repetition.

\section{Deleuze and the History of Philosophy}

Deleuze's early polemical reaction against Hegel must be contextualized, both sociologically and personally, in terms of the academic institutional milieu in which Deleuze was trained as a philosopher. (This milieu has been analyzed by Pierre Bourdieu in works such as Homo Academicus and The State Nobility).' When Deleuze was at the Sorbonne, doing philosophy meant doing the history of philoso- 
phy: in order to pass the agrégation examination in philosophy, which allowed one to teach in the French educational system, students were required to do close readings of classic texts in the history of philosophy. If they wanted to do "creative" work in this context, philosophy students necessarily had do so in the context of interpretive readings of this type. François Châtelet, a fellow student at the Sorbonne, and later a colleague at Vincennes, recounts a story that illustrates the manner in which Deleuze, as a student, was able to negotiate the tension between the university's requirements and his own interpretive invention:

I preserve the memory of a reading by Gilles Deleuze, who had to treat I don't know what classic theme of Nicholas Malebranche's doctrine before one of our most profound and most meticulous historians of philosophy, and who had constructed his demonstration, solid and supported with peremptory references, around the sole principle of the irreducibility of Adam's rib. At the expression of this adopted principle. the master turned pale, and obviously had to keep himself from intervening. As the exposition unfolded, the indignation was changed into incredulity, and then, by the end, into admiring surprise. And he justly concluded by making us all return the next week with our own analysis of the same theme. ${ }^{8}$

It is not by chance, therefore, that the work of Deleuze and Jacques Derrida - perhaps the two greatest philosophers of their generation-is frequently indexed on readings in the history of philosophy. (Both thinkers persistently return to the history of philosophy, even after "experiments" such as Derrida's The Post Card or Deleuze and Guattari's A Thousand Plateaus)." Moreover, at the time, writing on certain figures often carried a determinable political tag: in seventeenth-century studies, for instance, Cartesians tended to be on the right (Marion), Spinozists on the left (Deleuze, Althusser, Macherey, Balibar, Negri), and Leibnizians somewhere in the center (Serres). One had to choose one's preferred texts carefully.
There is also an individual component to this question that is often overlooked. It has been suggested that thought proceeds by way of the conflict of generations, the young rebelling against their elders. This seems particularly true with philosophers, whose initiation into philosophy can often be traced to a kind of theoretico-amorous admiration that at some point crystallizes around a particular teacher-what Michelle LeDoeuff has termed the "theoretico-erotic transference" (and which Plato simply called "Eros"). ${ }^{10}$ In the Abecedaire, Deleuze has traced his own initiation into philosophy, at age 14 , to his curious encounter with a teacher named Pierre Halwachs, whom he met on the beaches at Deauville. "Later, it was the faculty at the university, such as Ferdinand Alquié and Jean Hyppolite, who would occupy this role. What allows the student to overcome this initial transference, or the disciple to break with the master, LeDoeuff suggests, is precisely an institutional framework, which provides a third term beyond the dynamics of a dual relationship. In some well-known passages, Deleuze has evoked the effect these institutional constraints and related personal affiliations had on his philosophical formation:

I was taught by two professors, whom I liked and admired a lot: [Ferdinand] Alquié and [Jean] Hyppolite.... The former had long white hands and a stammer which might have been a legacy of his childhood, or there to hide a native accent, and which was harnessed to the service of Cartesian dualisms. The latter had a powerful face with unfinished features, and rhythmically beat out Hegelian triads with his fist, hanging his words on the beats. At the Liberation, we were still strangely stuck in the history of philosophy. We simply plunged into Hegel, Husserl and Heidegger; we threw ourselves like puppies into a scholasticism worse than that of the Middle Ages. . . After the Liberation, the history of philosophy tightened around us - without our realizing it-under the pretext of opening up a future of thought, which would also be the most ancient thought. The 'Heidegger question' did not seem to me to be

\section{PHILOSOPHY TODAY}


'Is he a bit of a Nazi?' (obviously, obviously) but 'What was his role in this new injection of the history of philosophy?'.... The history of philosophy has always been the agent of power in philosophy, and even in thought. It has played the role of a repressor: how can you think without having read Plato, Descartes. Kant, and Heidegger, and so-and-so's book about them? A formidable school of intimidation.... So I began with the history of philosophy when it was still being prescribed. For my part, I could not see any way of extracting myself. I could not stand Descartes, the dualisms and the cogito, or Hegel, the triad and the operation of negation.. 12

One can discern in this passage several "reactions" on Deleuze's part. There is a reaction against Cartesian dualisms and Hegelian triads, which is much a personal reaction against his teachers as a philosophical reaction. There is also a reaction against the institutionalization of the history of philosophy in the French university, and in particular the role Heidegger's thought played in it. Deleuze, for instance, never shared Heidegger's or Nietzsche's obsession with the Greeks; no doubt his avowed preference for the Stoics and Lucretius was at least in part a reaction against this "Helleno-philia." Finally, there is a reaction against what he calls the "scholasticism" of "the three H's"-Hegel, Husserl, and Heidegger-which was prevalent after the Liberation. Many French philosophers began their careers with books on Husserl-Levinas, Ricoeur, Derrida, Lyotard. Significantly, Deleuze never wrote directly on any of "the three H's," though he was obviously immersed in their work, and instead wrote his first book on Hume (Empiricism and Subjectivity, which was published in 1953), as if he wanted to add a fourth " $\mathrm{H}$ " of his own to the list. ${ }^{13}$

In fact, Deleuze's decision to write on Hume as a student is an important part of the story of his anti-Hegelianism. English philosophy, led by Bertrand Russell, had already gone through its own reaction against Hegel (at least as represented by Bradley) a full half-century earlier than did the French, but for quite spe- cific reasons. Drawing on the recent developments in logic stemming from the work of Frege and Peano, Russell developed the empiricist theme that relations are external to their terms, which became one of the standard criticisms laid against Hegel (for whom, like Leibniz, relations are internal to their terms). In France, this aspect of Anglo-American philosophy had been taken up by Jean Wahl, whom Deleuze would often cite, in his later writings, with regard to the priority Wahl gave to the conjunction "and" over the copula "is." 14 Throughout his career, Deleuze remained a great admirer of Russell, and was strongly antagonistic to the effects Wittgenstein's work had had on Anglo-American philosophy." Writing on Hume, and declaring himself to be an empiricist in the British mold, in other words, was already a direct anti-Hegelian provocation. ${ }^{16}$ For Hegel, empiricism itself was almost a non-philosophy, because it tried to grasp this, that, here, and now in an immediate manner, not realizing that notions such as "this," "that," "here," and "now" are universals that can never grasp the this, that, here, and now of sensible experience in an unmediated way. ${ }^{17}$ Deleuze dedicated his Hume book to his teacher, Jean Hyppolite-"a sincere and respectful homage," reads the dedication-and the provocation could hardly have been clearer: the 26 year-old student respectfully presenting to his Hegelian teacher a thesis on the greatness of empiricism.

Indeed, Deleuze's analysis of Hume's empiricism can be read as an explicit challenge to Hegel's characterization of empiricism. The empiricist thesis, in its usual formulation, is that knowledge is derived from experience, that is, the intelligible is derived from the sensible. But Deleuze shows that, for almost every specific idea that Hume analyzes in the Treatise on Human Nature (causality, the world, the self, God), the search for a linear path that would reduce the idea to a corresponding impression leads almost immediately to an impasse. Instead, Hume attempts to unravel a more complex tissue of principles (the principles of human nature: association and passion) 
that habitually bind together separate impressions in order to produce ideas which are in fact inferences, and which affirm more than is really "given." In shifting the emphasis to associationism, Deleuze argues, Hume carried empiricism to a higher power: if ideas contain neither more nor less than sensible impressions, it is precisely because relations are exterior and heterogeneous to their terms. The essential distinction in Hume, in other words, is not between impressions and ideas, between the sensible and the intelligible, but rather between two sorts of impressions and ideas: impressions and ideas of terms, and impressions and ideas of relations. In Hume, Deleuze argues, the empiricist world was deployed for the first time in its full extension-a conjunctive world of atoms and relations which would not find its complete development until Russell and modern logic. Through Hume, the early Deleuze seemed to be linking himself to the anti-Hegelian polemics of the early Russell.

Nonetheless, it could be argued that Empiricism and Subjectivity occupies a somewhat marginal position within Deleuze's corpus: Deleuze would eventually turn Hume's empiricism into what he would later come to call a "transcendental empiricism." This change was effected in the years between the publication of Empiricism and Subjectivity in 1953 and the appearance of Nietzsche and Philosophy in 1962, in which Deleuze's reaction against Hegel appears at its most intense. Deleuze has called this an "eight-year hole" in his life (1953-1961), during which he published very little. "I know what I was doing, where and how I lived during those years," he would later say, "but I know it almost abstractly, rather as if someone else were relating memories that I believe in but don't really have. ... That's what I find interesting in people's lives, the holes, the gaps, sometimes dramatic, but sometimes not dramatic at all. There are catalepsies, or a kind of sleepwalking through a number of years, in most lives. Maybe it's in these holes that movement takes place." ${ }^{18}$ Externally, during these eight years, Deleuze married and had his first child, and moved through a series of temporary academic posts, from the lycée in Orleans to the Sorbonne and CNRS in Paris. But a profound "intensive" movement of thought took place as well. Deleuze emerged pursuing a singular philosophical trajectory that would be worked out in a series of monographs on individual figures-Nietzsche (1962), Kant (1963), Proust (1964), Bergson (1966), and Masoch (1967) - and would culminate in Difference and Repetition.

\section{Deleuze's Methodology: The Role of "Becoming"}

Deleuze's use of the history of philosophy, however, would ultimately have a significance that went beyond the givens of these early institutional constraints. Deleuze obviously worked out his "creative" philosophy in the context of his monographs on various figures in the history of philosophy. But the reason he did so, he would later explain, is that, in order to write and think, he needed to work with "intercessors" with whom he could enter into a kind of "becoming" (past philosophers were intercessors of this type, as was Guattari, in the present). ${ }^{19}$ When reading Deleuze's monographs, as has often been noted, one has the distinct impression of entering a "zone" in which Deleuze's own project and that of the author at hand seem to become indiscernible. They constitute what Deleuze himself calls a "zone of indiscernibility": on the one hand, there is a becoming-Deleuze of the thinker at hand, as it were; and on the other hand, there is a kind of becoming-Spinoza on Deleuze's part, for instance, or a becoming-Leibniz, a becoming-Bergson, and so on. (This is what Bahktin called a "free indirect style" of writing.) ${ }^{20}$

This by-now familiar style, however, makes for some acute difficulties of interpretation: where does Deleuze end and, say, Spinoza begin? Where does an explication become an interpretation, and an interpretation, a creation (to use hermeneutical terms which Deleuze avoided)? These are not easy questions; such distinctions are, as Deleuze says, indiscern-

\section{PHILOSOPHY TODAY}


ible. Put crudely: In all Deleuze's readings, one moves from a fairly straightforward "explication" of the thinker at hand, to a more specifically Deleuzian "interpretation," which often makes use of concepts incorporated from outside thinkers (for instance, Deleuze interprets Spinoza in terms of Duns Scotus's concept of "univocity," and Leibniz in terms of the mathematical theory of "singularities," although neither of these terms appears Spinoza's or Leibniz's texts); and finally, one reaches a kind of "creative" point where Deleuze pushes the thought of the thinker at hand to its "differential" limit, purging it of the three great terminal points of metaphysics (God, World, Self), and thereby uncovering the immanent movement of difference in their thought. This is the point where Deleuze's own "system" would begin. Evaluating where these different points lie is one of the most challenging and difficult tasks in reading Deleuze-precisely because there are no clear-cut "points" where the transition is made.

Sometimes, however, interpreters have contented themselves with a quite different task: identifying Deleuze with (or distancing him from) certain philosophers in the history of philosophy, separating his "friends" from his "enemies." For instance, one could easily imagine drawing up the following four lists. The first would be a list of Deleuze's "canonical" philosophers, those to whom he devoted separate monographs: Hume, Nietzsche, Bergson, Spinoza, Leibniz. To this, one could then add a list of secondary names, philosophers Deleuze loves and refers to often, even though he never wrote a separate monograph on them: Lucretius, the Stoics, Duns Scotus, Maimon, Whitehead. Then there would be the list of Deleuze's ostensible enemies, which would include Plato, Kant, and Hegel. And finally, one could identify certain "hidden" thinkers that Deleuze confronts in fundamental manner, but who are not frequently discussed directly: notably Heidegger. With these lists in hand, one could begin to debate, for instance, about who Deleuze's "true" master is. Is it "really" Bergson, as Alain Badiou wants to claim? $?^{21}$ Is it Nietzsche? Is it Spinoza? Deleuze's own comments in certain interviews (notably the "Letter to Michel Cressole") tend to encourage this approach, when he says he detested Hegelianism, sought a way to overturn Platonism, thought of his study of Kant as "a book on an enemy," and that his work tends toward "the great Spinoza-Nietzsche identity."22

But the distinction between Deleuze's "friends" and "enemies," or the identification of Deleuze's "true" masters, is at best a preliminary exercise: necessary, perhaps, but certainly not sufficient. The fact is that Deleuze reads every philosopher in the history of philosophy - friend or enemy - in the same manner, following the same strategy, pushing each thinker, so to speak, to their differential limit. (Indeed, this is a point of affiliation with Hegel: Hegel pushes thought to its point of contradiction; Deleuze, to the point of difference.) Deleuze indeed describes his Kant book as "a book on an enemy," but elsewhere he notes, more accurately, that Kant was one of the great philosophers of immanence, and Deleuze unhesitatingly places himself squarely in the post-Kantian heritage (even if Kant was unable to push the thought of immanence to its necessary conclusion, that is, to its differential conclusion). ${ }^{23}$ Conversely, and for the exact same reason, Deleuze often departs from his "friends": he rejects Bergson's critique of intensity in Time and Free Will; his Leibnizianism is a Leibnizianism minus God, his Spinozism is a Spinozism minus substance; and Spinoza himself defined determination as negation-a position from which Deleuze broke strongly in his earliest work. But this does not mean that Deleuze is "anti-Spinoza" or "anti-Leibniz" or "anti-Bergson"-any more than he is simply "anti-Hegel," for the same reason. Such characterizations, while not entirely inaccurate, are far too simplistic; they miss the movement and "becoming" of Deleuze's thought, both in itself and in its complex relation to the history of philosophy.

DELEUZE CONTRA HEGEL 


\section{The Post-Kantian Tradition: The Role of Maimon.}

Why then didn't Deleuze write directly on Hegel, the philosopher he says he detested, and push him to his differential limit? Jacques Derrida, in his early work, suggested one possible reason for avoiding a direct confrontation with Hegel: it is impossible to oppose Hegel, because opposition is the motor of the Hegelian system, and to oppose Hegel is thus to become part of the system. This, however, was not an issue for Deleuze, and his early work follows a quite different trajectory than Derrida's, despite certain points of convergence between their work. For instance, one does not find in Deleuze the kind of critique of "binary oppositions" that one finds in Derrida's early work. Nor does one find a concept of "closure" in Deleuze's writings: neither structural closure, since Deleuze from the start defined structures as open and differential (what he called structuralism is what was later termed "post-structuralism), nor the closure of metaphysics, since, far from seeing metaphysics as having exhausted its possibilities, Deleuze frequently dipped into the history of philosophy in order to retrieve, rejuvenate, and transform modes of thought that had been closed off (such as the tradition of univocity inaugurated by Duns Scotus-a trajectory that had been blocked by Christian orthodoxy). Though Derrida and Deleuze both participated in a shared anti-Hegelian reaction, they nonetheless posed their "anti-Hegelian" problems in different manners, which in turn led them to pursue quite different philosophical trajectories.

This brings us back, then, to the question of the specificity of Deleuze's anti-Hegelian trajectory. On this score, it would be hard to overemphasize the role played in Deleuze's thought by the eighteenth-century philosopher Salomon Maimon. Maimon is an obscure figure, largely forgotten in the English-speaking world. In France, however, he remains semi-canonical (Martial Gueroult wrote an important book on Maimon), and he exerted an enormous influence on Deleuze, who considered him "a great, great philosopher." ${ }^{24}$ Maimon, a contemporary of Kant, was a Polish-Russian Jew who never attended a university, receiving his sole education from the Talmudic tradition while training to be a rabbi. $\mathrm{He}$ was exiled (Spinoza-like) from his community because of his unorthodox and radical views, and lived for several years as a wandering beggar, spending much of his time in taverns, and in constant poverty. He was crude, naïve, and simple, sometimes embarrassingly outspoken, though he spoke an ad hoc mixture of Hebrew, Lithuanian, Yiddish, and Polish that few could understand. Somehow, he made his way to Berlin, and made contact with some of the intelligencia there (including Mendelssohn, who, as a skilled linguist, was apparently one of the few people who could understand what he was saying). In Berlin, he fell under the spell of Kant's critical philosophy, and wrote a manuscript on it entitled Essay on Transcendental Philosophy. ${ }^{25}$ In April 1789, Marcus Herz, a old student and friend of Kant's, sent his former teacher a copy of Maimon's manuscript, recommending it to him and hoping it would receive Kant's blessing before publication. Kant, who was sixty-six, in failing health, and eager to finish the third Critique (which would not appear until a year later), was annoyed, and nearly returned the manuscript to Herz unopened. Six weeks later, however, Kant finally wrote back to Herz: "But one glance at the work made me realize its excellence, and that not only had none of my critics understood me and the main questions as well as Mr. Maimon does, but also very few men possess so much acumen for such deep investigations as he.,"26 The letter continued with a lengthy reply to two sections of Maimon's manuscript. It was, to say the least, a remarkable turn of events.

But that is not the end of the story. Maimon's book was published, and read by another young philosopher, who was even more impressed than Kant. "My respect for Maimon's talent is limitless," he wrote in a let-

\section{PHILOSOPHY TODAY}


ter to Reinhold. "I firmly believe, and am ready to prove, that through Maimon's work the entire Kantian philosophy, as it is understood by everyone including yourself, is completely overturned. ... All this he has accomplished without anyone's noticing it and while people even condescend to him. I think that future generations will mock our century bitterly."27 This is from a letter by Fichte, who was dazzled by Maimon's book. Indeed, not only Fichte's philosophy, but the entire post-Kantian tradition-usually marked by the names Fichte, Schelling, and Hegel-can be said to have been generated by the critiques Maimon leveled against Kant in the midst of the fervor created by the critical philosophy. As Frederick Beiser says, in his superb study The Fate of Reason, to study Fichte, Schelling, or Hegel without having read Maimon is like studying Kant without having read Hume. ${ }^{28}$ Deleuze, to be sure, was aware of Maimon's role in the post-Kantian tradition, and his strategy in approaching that tradition seems to have been as follows: rather than attacking Hegel directly, he instead went back to Maimon, that is, to the polemics that generated the post-Kantian tradition in the first place, and took them up anew, in his own manner, in order to formulate an alternate solution to those same problematics.

What was it, then, that Kant, Fichte, and Deleuze found so remarkable in Maimon's manuscript? For his part, Deleuze, at least, seems to have taken up three elements of Maimon's thought in his early work. First, within the context of the critical tradition, Maimon is the great philosopher of immanence. ${ }^{29}$ Kant conceived of his transcendental philosophy as a purely immanent critique of reason, and insofar as Deleuze conceives of his own philosophy as the construction of a "plane of immanence," he aligns himself squarely within the critical tradition. ${ }^{30}$ Maimon's greatness, however, was to have pushed the immanent claims of Kant's philosophy to their logical conclusion: almost all Maimon's critiques of Kant are aimed at eliminating the illegitimate vestiges of transcendence that still re- main in Kant, given the presuppositions of a transcendental subject-which Deleuze himself, of course, will break with. (The "thing-in-itself," for instance, as Jacobi had already argued, is an illegitimate transcendent application of the category of causality).

Second, from the viewpoint of immanence, Maimon's primary objection to Kant was that he had ignored the demands of a genetic method. This means two things. Kant assumes that there are a priori "facts" of reason (the "fact" of knowledge in the first Critique, and the "fact" of morality in the second Critique) and simply seeks the "condition of possibility" of these facts in the transcendental-a vicious circle that makes the condition (the possible) refer to the conditioned (the real) while reproducing its image. Maimon argues that Kant cannot simply assume these facts, but has to show that they can be deduced or engendered immanently from reason alone as the necessary modes of its manifestation. The critical philosophy, in other words, cannot be content with a method of conditioning, but must be transformed into a method of genesis. An important consequence follows from this. Maimon argues that even if the categories, in Kant, are applicable to possible experience, they can never specify what objects they apply to in real experience. Causality may be a necessary concept for any possible experience, for example, but the concept itself gives us no means of distinguishing, within real experience, between what are necessary and universal connections and what are merely contingent constant conjunctions. Hume's skepticism, in other words, remains unanswered, and Kant's famous duality between concept and intuition remains unbridgeable. Maimon was the first to say that this duality could only be overcome through the formulation of a principle of difference: whereas identity is the condition of possibility of thought in general, he argued, it is difference that constitutes the genetic condition of real thought.

These two exigencies laid down by Maimon-the search for the genetic elements of real thought (and not merely the conditions

DELEUZE CONTRA HEGEL 
of possible thought), and the positing of a principle of difference as the fulfillment of this condition-reappear like a leitmotif in almost every one of Deleuze's books up through 1969 , even if Maimon's name is not always explicitly mentioned. (Indeed, these are the two primary components of Deleuze's "transcendental empiricism)." The post-Kantian philosophers, starting with Fichte, had themselves taken up Maimon's challenge, but in some fashion each of them still subordinated the principle of difference to the principle of identity. In Fichte, for example, identity is posited as the property of the thinking subject, with difference appearing only as an extrinsic limitation imposed from without (the non-self). Hegel, against Fichte, attempted to give a certain autonomy to the principle of difference by placing difference and identity in dialectical opposition; but even in Hegel, contradiction always resolves itself, and in resolving itself, it resolves difference by relating it to a ground. ${ }^{32}$ (This is the movement one finds in Hegel's Logic: identity, difference, differentiation, opposition, contradiction, ground). Deleuze returns to Maimon, it seems to me, in order to take up the option that was not pursued as such by post-Kantian philosophy (though its closest precursor is no doubt Schelling). In Deleuze, the principle of "difference-in-itself" is made to function as the genetic element of real experience: difference is the principle from which all other relations (identity, analogy, resemblance, opposition, contradiction, negation) are derived. ${ }^{33}$

Third, in pursuing these immanent aims, Maimon produced a revised transcendental philosophy of his own which he described as a Koalitionssystem, a "coalition system" that reached back to the pre-Kantians and incorporated elements of Hume, Spinoza, and Leibniz: a Kantian philosophy that begins with Humean skepticism and winds up with the rationalism of Leibniz and Spinoza. In this sense, Maimon functions as a true precursor to Deleuze, who himself - not coincidentally-made use of Hume, Spinoza, and Leibniz in formulating his own coalition system. (Even in The Fold, a late work, several aspects of Deleuze's reading of Leibniz are explicitly derived from Maimon.) ${ }^{34}$ But Deleuze does more than simply pick up on Maimon's pre-Kantian trio. Perhaps more importantly, in his early work, Deleuze begins to trace out an alternate post-Kantian tradition that will ultimately link up Maimon with later philosophers such as Nietzsche and Bergson, thereby constructing, as it were, his own subterranean or "minor" post-Kantian tradition. For the post-Kantian tradition of Fichte, Schelling, and Hegel, in other words, Deleuze will substitute his own trio of Maimon, Nietzsche, and Bergson.

This is the reason Deleuze's writings on Bergson and Nietzsche are infused with Maimonian themes, even if they are not always explicitly identified as such. ${ }^{35}$ Consider, for example, the following text from Nietzsche and Philosophy." Deleuze notes that it was the post-Kantians who "demanded a principle which was not merely conditioning in relation to objects, but which was also truly genetic and productive (a principle of internal difference or determination)." That is a statement of Maimon's critiques, though Maimon's name only appears in the footnote. "If Nietzsche belongs to the history of Kantianism," Deleuze continues, "it is because of the original way he deals with these post-Kantian [i.e., Maimonian] demands." How does Nietzsche satisfy these demands? On the one hand, Deleuze argues, Nietzsche, using his own "genealogical" method, was able to give a genetic account of knowledge and morality that was missing in Kant: not a critique of false knowledge or false morality, but a critique of true knowledge and true morality, and indeed of the value of truth itself. ${ }^{37}$ On the other hand, the genealogical method itself led Nietzsche back to a principle of difference as the condition of the real, that is, the difference between active and reactive modes of existence that serve as the principle of all value. "Nietzsche," Deleuze concludes, "seems to have sought a radical transformation of Kantianism, a re-invention of the critique which Kant betrayed at the same

\section{PHILOSOPHY TODAY}


time as he conceived it." The central theme of Nietzsche and Philosophy is that Nietzsche was the first philosopher to have truly managed to fulfill Maimon's post-Kantian demands. (The central chapter of the book is entitled, precisely, "Critique.") Nietzsche and Philosophy, in other words, wears its anti-Hegelianism on its sleeve, but its more profound theses are derived from Maimon and are aimed at a wholesale revision of the post-Kantian tradition. It is not difficult to trace out the same Maimonian influences in Deleuze's work on Bergson. $^{38}$

\section{Hegel and the Dialectic}

Maimon, in short, clearly influenced the early Deleuze in at least these three areas: the adherence to the position of immanence, the posing of the problem of the genetic method and the principle of difference, and the construction of a coalition system integrating elements of Hume, Spinoza, and Leibniz. These themes provide an important context in which to place-and to assess-Deleuze's relation to Hegel and the post-Kantian tradition. Certain commentators have contended that the portrait of Hegel presented in Nietzsche and Philosophy is simplistic, and to a certain degree this may be true. ${ }^{39}$ But if Deleuze never wrote directly on Hegel, and if his characterizations of Hegel are largely made in passing, it is because these criticisms were relevant only in relation to Deleuze's larger project, which was primarily indexed on Kant, not Hegel (transcendental empiricism). From this viewpoint, Deleuze's persistent criticism is that Hegel provides an inadequate solution to Maimon's primary post-Kantian problematic: the search for the conditions of real and not merely possible experience.

Put schematically, Deleuze's critiques are directed against several essential components of the Hegelian dialectic. First, Hegel's dialectic begins with concepts as generalities. "In this type of dialectical method, one begins with concepts that, like baggy clothes, are much too big: the One in general, the multiple in general, nonbeing in general. ... In such cases, the real is recomposed with abstracts" and generali ties. ${ }^{\text {*1 }}$ Second, in order to compensate for the generality of the concept, Hegel appeals to a method of opposition or contradiction. But "of what use is a dialectic that believes itself to be reunited with the real, when it compensates for the inadequacy of a concept that is too broad by invoking the opposite concept, which is no less broad and general?" (The theory of concepts developed in What is Philosophy? should be assessed in light of this critique.) Finally, the movement of contradiction is driven by means of the labor of the negative. In Hegel, the sign of difference is "not-X." The principle of identity " $X$ is $X$ " can be reformulated as " $X$ is not not-X," which means that a thing includes in its being this non-being that it is not: the being of a thing is inseparable from the negation of the negation (is not. . . not). ${ }^{42}$ Summarizing these critiques, Deleuze writes in Difference and Repetition that the "objection to Hegel is that he does not go beyond false movement-in other words, the abstract logical movement of 'mediation.",

However, these explicit criticisms of Hegel-against contradiction, against negation, against mediation-find their force and validity only in the alternate vision of "dialectics" that Deleuze himself provides. True to his conception of philosophy as the creation of concepts, Difference and Repetition (particularly in its fifth chapter, "Ideas and the Synthesis of Difference") attempts to develop a new concept of dialectics, which is more or less synonymous with the concept of "problematics": dialectics is the art of posing or construction problems, expressed in the form of Ideas (which Deleuze, like Kant, distinguishes from concepts). In this manner, Deleuze places himself squarely within the heritage of his so-called "enemies"- the great philosophers of dialectics: Plato and Aristotle, Kant, and Hegel - and develops his concept of dialectics through them. In this sense, Deleuze's reworking of dialectics extends beyond both Hegel and Kant.

DELEUZE CONTRA HEGEL 
Aristotle, for instance, defined dialectics as the art of posing problems as the subject of a syllogism, while analytics gives us the means of resolving the problem by leading the syllogism to its necessary conclusion. But Aristotle was content to derive his problems from the propositions of common sense (for instance, "Is rational animal the definition of man or not?"), and to assess their legitimacy by considering "the opinions accepted by. . . the majority" in order to relate problems to general points of view, which thereby to form the places (the topoi) that allow problems "to be established or refuted in discussion." (Put crudely, this is the kind of dialectics of opinion one finds on TV news shows, where the representatives of opposing viewpoints or propositions argue out their respective positions.) For Deleuze, this is a fundamental perversion of dialectics. "Whenever the dialectic 'forgets' its intimate relation with Ideas in the form of problems," he writes, "it loses its true power and falls under the sway of the power of the negative, necessarily substituting for the ideal objectivity of the problematic a simple confrontation between opposing, contrary, or contradictory propositions. This long perversion begins with the dialectic itself [that is, with Plato], and attains its extreme form in Hegelianism." 45

Plato, for his part, recognized the profound link between Ideas and problems; but if he posited Ideas as transcendent essences, it was because he saw them as responses to a particular problem, or rather, a particular form of question, namely, the question "What is. . . ?" Kant's genius, in the "Transcendental Dialectic," was to assign a new status to Ideas: lacking any determinate object, he argued, Ideas are necessarily "problematic," which means that the true object of an Idea is the problem as such. ${ }^{46}$ Kant, however, was still willing to preserve the transcendent status of Ideas as "foci" or "horizons" that transcend any possible experience, and it was on this point that Maimon proposed his fundamental inversion of Kant. Maimon insisted that Ideas are immanent to experience, that is, they are present in sensible nature and can be comprehended by the understanding. It is this immanent conception of dialectics that Deleuze attempts to push to its limit in Difference and Repetition. "Problems do not exist only in our heads," he writes, "but occur here and there in the production of an actual historical world., ${ }^{, 47}$ For this reason, a purely immanent dialectic must be derived from questions such as Who? Where? When? How? How much? How many? In which cases? - which are no longer questions of essence, but rather "those of the accident, of the event, of multiplicity $\longrightarrow$ of difference." ${ }^{48}$

This, then, is the context in which Deleuze's relation to Hegel should be understood. Deleuze is certainly not anti-dialectical, since he explicitly places himself in a long tradition of dialectical thought. At one level, he's not entirely anti-Hegelian, insofar as he is attempting to work out and respond to a similar set of post-Kantian problems; but at another level, he is anti-Hegelian in that he pursues these problems in a different manner than Hegel. In this sense, the Deleuze-Hegel relation needs to be assessed less in terms of Deleuze's explicit comments "against" Hegel than in terms of the alternate conception of dialectics he develops through his oeuvre: a dialectic in which an affirmative conception of the "problematic" is substituted for the "labor of the negative," and a principle of difference is substituted for the movement of opposition or contradiction.

\section{ENDNOTES}

1. Gilles Deleuze, Negotiations, 1972-1990, trans. Martin Joughin (New York: Columbia University Press, 1995), p. 6.
2. Gilles Deleuze, Nietzsche and Philosophy, trans. Hugh Tomlinson (New York: Columbia University Press, 1983).

\section{PHILOSOPHY TODAY}


3. Gilles Deleuze, Difference and Repetition, trans. Paul Patton (New York: Columbia University Press. 1984), p. ix.

4. Vincent Descombes, Modern French Philosophy. trans. L. Scott-Fox and J. M. Harding (Cambridge: Cambridge University Press, 1980).

5. Michel Foucault. L'ordre du discours (Paris: Gallimard, 1971), p. 74, as cited in Descombes, Modern French Philosophy, p. 12.

6. See Deleuze, Difference and Repetition, where this conception of dialectics is linked to the notion of the problematic: "Whenever the dialectic 'forgets' its intimate relation with Ideas in the form of problems. . it loses its true power" (p. 164); "Problems are always dialectical: the dialectic has no other sense" (p. 179)

7. Pierre Bourdieu, Homo Academicus, trans. Peter Collier (Stanford: Stanford University Press, 1988); The State Nobility: Elite Schools in the Field of Power, trans. Lauretta C. Clough (Stanford: Stanford University Press, 1988).

8. François Châtelet, Chronique des idées perdues (Paris: Editions Stock, 1977), p. 46. Michel Tournier provides a similar tribute in The Wind Spirit: An Autobiography, trans. Arthur Goldhammer (Boston: Beacon Press, 1988) pp. 127-28: Deleuze "possessed extraordinary powers of translation and rearrangement: all the tired philosophy of the curriculum passed through him and emerged unrecognizable but rejuvenated, with an air of freshness, undigestedness, and raw newness, utterly startling and discomfiting our weakness and laziness." See also pp. 134-35 and 157.

9. Jacques Derrida. The Post Card, trans. Alan Bass (Chicago: University of Chicago Press, 1987); Gilles Deleuze and Félix Guattari, A Thousand Plateaus, trans. Brian Massumi (Minneapolis: Minnesota University Press, 1987).

10. See Michèle LeDoeuff, "Long Hair, Short Ideas," in The Philosophical Imaginary, trans. Colin Gordon (Stanford: Stanford University Press, 1989), pp. 105-06. Deleuze himself makes a similar point in Difference and Repetition: "There is something amorous-but also something fatal—about all education" (p. 23).

11. See "E as in 'Enfance' (Childhood)" in Gilles Deleuze's $A B C$ Primer, with Claire Parnet, pre- sented by Charles Stivale, at http:/www.Langlab. wayne.edu/Romance/FreD_G/ABCl.html.

12. Gilles Deleuze and Claire Parnet, Dialogues, trans. Hugh Tomlinson and Barbara Habberjam (New York: Columbia University Press, 1987), pp.12-14.

13. Gilles Deleuze, Empiricism and Subjectivity: An Essay on Hume's Theory of Human Nature, trans. Constantin V. Boundas (New York: Columbia University Press, 1991).

14. See A Thousand Plateaus, p. 526, n 32: "Jean Wahl's works contain profound reflections on this sense of 'and,' on the way it challenges the primacy of the verb "to be.",

15. See "W as in 'Wittgenstein"," in Gilles Delewze's $A B C$ Primer, with Claire Parnet.

16. See Deleuze and Parnet, Dialogues, p. vii: I have always felt that I am an empiricist, that is, a pluralist."

17. See G. W. F. Hegel, Phenomenology of Spirit, trans. A. V. Miller (Oxford: Oxford University Press, 1979), section on "Sense Certainty." See also Deleuze"s comment in Nietzsche and Philosophy, p. 4: "Hegel wanted to ridicule pluralism. identifying it with a naive consciousness which would be happy to say 'this, that, here, now'-like a child stuttering out its most humble needs."

18. Deleuze, Negotiations, p. 138.

19. See ibid., pp. 121-24. The French term "Intercesseurs" in the title is translated as "Mediators."

20. Deleuze analyzes this notion in his cinema books, but it seems equally applicable to his own work. See Gilles Deleuze, The Movement-Image, trans. Hugh Tomlinson and Barbara Habberjam (Minneapolis: University of Minnesota Press, 1986), p. 73: free indirect discourse "testifies to a system which is always heterogeneous, far from equilibrium."

21. Alain Badiou, Deleuze: The Clamour of Being, trans. Louise Burchill (Minneapolis: University of Minnesota Press, 2000), p. 39: "Deleuze is a marvelous reader of Bergson, who, in my opinion, is his real master, far more than Spinoza, or perhaps even Nietzsche."

22. Negotiations, p. 135, translation modified.

23. See ibid., p. 145: "Setting out a plane of immanence, tracing out a field of immanence, is something all the authors I've worked on have done (even Kant-by denouncing any transcendent application of the syn-

DELEUZE CONTRA HEGEL 
theses of the imagination, although he sticks to possible experience rather than real experimentation." Moreover, the central chapter of Nietzsche and Philosuphy is entitled "Critique": beneath the explicit "anti-Hegelian" theme of the book there lies a more profound engagement with Kant and the post-Kantian tradition in general, and of which Hegel is only a part (see pp. 51-52 for Deleuze's comments on the relation between Nietzsche and post-Kantianism).

24. Gilles Deleuze, seminar of 14 March 1978, on-line at http://www.imaginet.fr/deleuze. Martial Gueroult's book is La philosophie transcendentale de Salomon Maïmon (Paris: Alcan, 1929). Gueroult's subsequent work, L'Evolution er la structure de la Doctrine de la Science chez Fichte (Paris: Les Belles Lettres, 1930), also contains an important discussion of Maimon. Maimon recounted his extraordinary and tragic life in his autobiography: Salomon Maimon: An Autobiography, with Additions and Notes, trans. J. Clark Murray (London, 1888); this truncated translation is still the only work of Maimon's available in English.

25. Salomon Maimon, Versuch über die Tranzendentalphilosophie (Berlin: Vos, 1790). In French: Essai sur la Philosophie Transcendentale, trans. Jean-Baptiste Scherrer (Paris: Vrin, 1989). There is no English translation.

26. Immanuel Kant, Philosophical Correspondence, ed. and trans. Arnulf Zweig (Chicago: University of Chicago Press, 1967), p. 151. Five years later, however, after leaving several letters from Maimon unanswered, Kant expressed a certain incomprehension of his project in a letter to Reinhold: "For the past three years or so, age has affected my thinking. ... I feel an inexplicable difficulty when I try to project myself into other people's ideas, so that I seem unable to grasp anyone else's system and to form a mature judgment of it.... This is the reason why I can turn out essays of my own, but, for example, as regards the 'improvement' of the critical philosophy by Maimon, ... I have never really understood what he is after and must leave the reproof to others" (letter to K. L. Reinhold. 28 March 1794, pp. 211-12). The assessment, however, was not limited to Maimon: "I cannot even make Professor Reinhold's work clear to me...." (Letter to J. S. Beck. I July 1794, p. 217).
27. J. G. Fichte, Briefwechsel, III/2, p. 282, as cited in the introduction to Immanuel Kant, Philosophical Correspondence, ed. and trans. Arnulf Zweig (Chicago: University of Chicago Press, 1967), p. 28.

28. Frederick C. Beiser, The Fate of Reason: German Philosophy From Kant to Fichte (Cambridge, Mass.: Harvard University Press, 1987), p. 286. Beiser's superb study contains a chapter (pp. 285-323) analyzing the main themes of Maimon's thought. His articles "Introduction: Hegel and the Problem of Metaphysics," in The Cambridge Companion to Hegel, ed. Frederick C. Beiser (Cambridge: Cambridge University Press, 1993), pp. 1-24, and "The Context and Problematic of post-Kantian Philosophy," in A Companion to Continental Philosophy, ed. Simon Critchley (Oxford: Blackwell, 1998), pp. 21-34, discuss Maimon's influence on post-Kantian thought. In English, one can also consult: Samuel Atlas. From Critical to Speculative Idealism: The Philosophy of Salomon Maimon (The Hague: Martinus Nijhoff, 1964); Samuel H. Bergman, The Phiiosophy of Salomon Maimon, trans. Noah J. Jacobs (Jerusalem: Magnes, 1967); and Jan Bransen. The Antinomy of Thought : Maimonian Skepticism and the Relation between Thoughts and Objects (Dordrecht and Boston : Kluwer Academic Publishers, 1991).

29. Gueroult, Fichte, p. 110: "For Maimon, the only untouchable aspect of the critical philosophy was the Copernican spirit of the method: nothing can be advanced that cannot be immediately justified from the viewpoint of the immanent consciousness in which alone the relation of the subject to the object must be determined."

30. On immanent critique in Kant, see Nietzsche and Philosophy, p. 91; on Deleuze's relation to Kant, see $\mathrm{Ne}$ gotiations, p. 145.

31. Deleuze, for instance, applies this Maimonian formula at various instances to the work of Schelling. Bergson, Nietzsche, Foucault, and even Pasolini: (1) "One must not raise oneself to conditions as to conditions of possible experience, but as to conditions of real experience: Schelling had already proposed this aim and defined his philosophy as a superior empiricism. The formula is valid for Bergsonism as well" ("La conception de la différence chez Bergson," p. 85). (2) "The Nietzsche and the Kantian conceptions of critique are opposed on five main points: 1 . Ge-

\section{PHILOSOPHY TODAY}


netic and plastic principles that give an account of the sense and value of beliefs, interpretations and evaluations rather than transcendental principles which are conditions for so-called facts" (Nietzsche and Philosophy, p. 93). (3) "Foucault differs in certain fundamental respects from Kant: the conditions are those of real experience, and not of possible experience" (Foucault, p. 60 [the final phrase of this sentence is inadvertently omitted from the English translation]). (4) "If it is worth making a philosophical comparison, Pasolini might be called post-Kantian (the conditions of legitimacy are the conditions of reality itself) while Metz and his followers remain Kantians (the falling back of principle upon fact)" (The Time-Image, p. 286 , note 8 , translation modified).

32. See G. W. F. Hegel, Science of Logic, trans. A. V. Miller (London: George Allen \& Unwin, 1969), Vol. 1, Book 2, Section 1, II, "Determinations of Reflection" (Identity, Difference, Contradiction).

33. Gueroult, in Fichte, vol. 1, pp. 126-27, shows that in Maimon himself the relationship between difference and identity remains highly ambiguous, oscillating between all these positions; our discussion of Maimon here is necessarily simplified.

34. See Gilles Deleuze, Le Pli: Leibniz et le Baroque (Paris: Minuit, 1988), Chapter 7, "Perception dans les plis," esp. p. 118.

35. The following comment from Nietzsche and Philosophy is equally applicable to Deleuze: "The philosophical learning of an author is not assessed by number of quotations, but by the apologetic or polemical directions of his work itself" (p. 162).

36. Nietzsche and Philosophy. pp. 51-52. The footnote refers the reader to Gueroult's book on Maimon, as well as Jules Vuillemin's L'Héritage kantian et la révolution copernicienne (Paris: Presses
Universitaire de France, 1954), which Deleuze cites throughout his writings.

37. For Nietzsche's problematization of knowledge and morality, see the Genealogy of Morals, trans. Walter Kaufman and R. J. Hollingdale (New York: Random House, 1967): "The will to truth requires a critique-let us thus define our own task - the value of truth must for once be experimentally called into question" (Essay III, $\$ 24$, p. 153). "We need a critique of moral values, the value of these values must first be brought into question" (Preface, $\S 6$, p. 20).

38. See Gilles Deleuze, Bergsonism. trans. Hugh Tomlinson and Barbara Habberjam (New York: Zone Books, 1988). (1) On the genetic method, and the conditions of real (and not merely possible) experience, see pp. 23, 26-28. 96-98 (Bergson's critique of the category of the possible). (2) On the principle of difference, see chapter 5, pp. 91-93, and Deleuze's early article, "Bergson's Conception of Difference," trans. Melissa McMahon, in The New Bergson, ed. John Mullarkey (Manchester: Manchester University Press, 2000).

39. See, for instance, Daniel Breazeale's criticisms in "The Hegel-Nietzsche Problem," in NietzscheStudien 4 (1975), pp. 146-64.

40. Deleuze, Bergsonism, p. 44.

41. Ibid.

42. See Deleuze, Seminar of 14 March 1978.

43. Deleuze, Difference and Repetition, p. 8.

44. Aristotle, Topics, I, 100a30-100b22; see Difference and Repetition, p. 160.

45. Ibid., p. 164.

46. See Deleuze's analysis in ibid.. pp. 168-70.

47. Ibid., p. 190.

48. Ibid., p. 188.

\section{University of New South Wales, Sydney 2052, Australia}

